기 생 충 학 잡 지 제 26 권 제 2 호

The Korean Journal of Parasitology

Vol. 26, No. 2, 127 132, June 1988

\title{
Stictodora sp. (Trematoda: Heterophyidae) Recovered from a Man in Korea
}

\author{
Jong-Yil Chai, Sung-Jong Hong*, Soon-Hyung Lee and Byong-Seol Seo** \\ Department of Parasitology and Institute of Endemic Diseases, \\ College of Medicine, Seoul National University, Seoul 110-460, Korea
}

\begin{abstract}
Two adult specimens of heterophyid fluke, which belong to the genus Stictodora, were collected from the stool of a 24-year old man after chemotherapy. The flukes were morphologically characterized by their small body size $(0.90 \sim 0.98$ $\mathrm{mm}$ long and $0.38 \mathrm{~mm}$ wide) and peculiar structure of ventrogenital sac with armed gonotyl (with about $12 \sim 15$ spines) not enveloping genital pore. Species identification is deferred until more worms are obtained, although they closely resemble Stictodora fuscatum (Onji and Nishio, 1916). The patient used to eat raw flesh of mullets and gobies, which are regarded as the infection source of Stictodora sp., together with 3 other kinds of heterophyids described elsewhere. This is the first record of human Stictodora infection in the literature.
\end{abstract}

Key words: Stictodora sp., Heterophyidae, intestinal trematode, intestinal fluke

\section{INTRODUCTION}

Heterophyid flukes (family Heterophyidae), which are small in body size and inhabit in the intestinal tract of vertebrate hosts (Yamaguti, 1958), are not uncommon parasites of humans in various parts of the world (Beaver et al., 1984). At least 20 species belonging to 8 genera (Heterophyes, Heterophyopsis, Metagonimus, Stellantchasmus, Centrocestus, Pygidiopsis, Haplorchis and Procerovum) are known to occur in human intestine (Ito, 1964; Seo et al., 1984 b).

Stictodora sp., another group that belong to the family Heterophyidae, have been recorded

* Present address: Department of Parasitology, College of Medicine, Gyeong-Sang Naticnal University, Jinju 660-280, Gyeongsang Nam-do, Korea

** Present address: Department of Parasitology, College of Medicine, Inha University, Inchon 402-020, Korea from fish-eating birds and mammals (Yamaguti, 1958), but had never been described from human. In August 1983, the authors collected a few hundred specimens of 4 different kinds of heterophyid trematodes, from the stool of a young man who used to eat raw flesh of brackish water fishes, after chemotherapy with praziquantel. Among them, two specimens were classified to belong to the genus Stictodora, with which the present paper mainly concerns.

\section{CASE RELORD}

The patient is Han, K-J, 24-year old man whose residence before moving to Seoul in April 1983 was at a coastal village in Koheung-gun, Jeonranam-do (Province). He is the identical person with Case 1 of Seo et al. (1984 a \& b) and Case 2 of Chai et al. (1984).

For convenience, brief case description is also given here. He consulted a physician because of easy fatiguability and general weakness, 
indigestion and occasional diarrhea, and palpitation. At stool examination, eggs of heterophyids and Diphyllobothrium latum were found. He stated he used to eat raw flesh of various kinds of brackish water fishes such as mullets, perches and gobies. Praziquantel $15 \mathrm{mg} / \mathrm{kg}$ in single dose was orally given and purgation was done with magnesium salt. The watery stool was collected to search for expelled parasites. Together with a tapeworm, total 259 adult specimens of heterophyid trematodes were recovered and classified into 4 species; Stellantchasmus falcatus (Seo et al., 1984a), Heterophyopsis continua (Seo et al., 1984b), Heterophyes nocens (Chai et al., 1984) and Stictodora sp. (present paper).
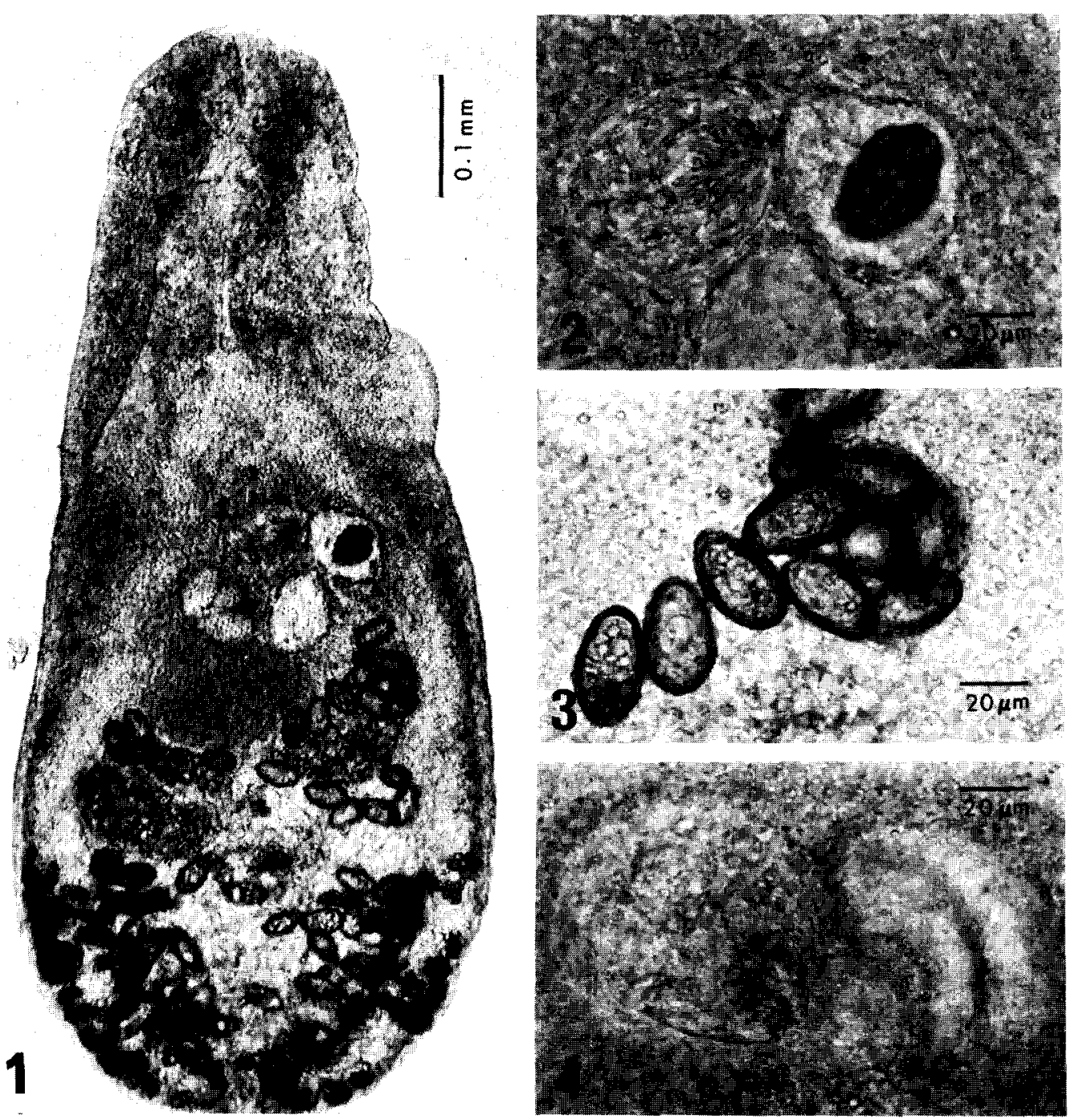

Fig. 1 4. Stictodora sp. recovered from a man after chemotherapy.

1. Whole specimen. Lateral margins are a little distorted due to anthelmintic treatment (see details of organs in Fig. 5).

2. Ventrogenital sac of the worm in Fig. 1. Note the number and arrangement of gonotyl spines (left) and the genital atrium (right).

3. Intrauterine eggs, with thick-shell.

4. Ventrogenital sac of the other worm, 


\section{DESCRIPTION OF WORMS}

\section{Stictodora sp.}

Measurements were done after formalinfixation under pressure. Body small, pyriform or ovoid (Figs. 1\& 5), $0.90 \sim 0.98 \mathrm{~mm}$ long and $0.38 \mathrm{~mm}$ wide. Oral sucker round, $0.08 \mathrm{~mm}$ in diameter. Prepharynx short. Pharynx $0.06 \sim$ $0.07 \mathrm{~mm}$ in diameter. Esophagus slender, 0.07 mm long. Ceca wide, thick-walled, and a little convoluted just after bifurcation, and extended

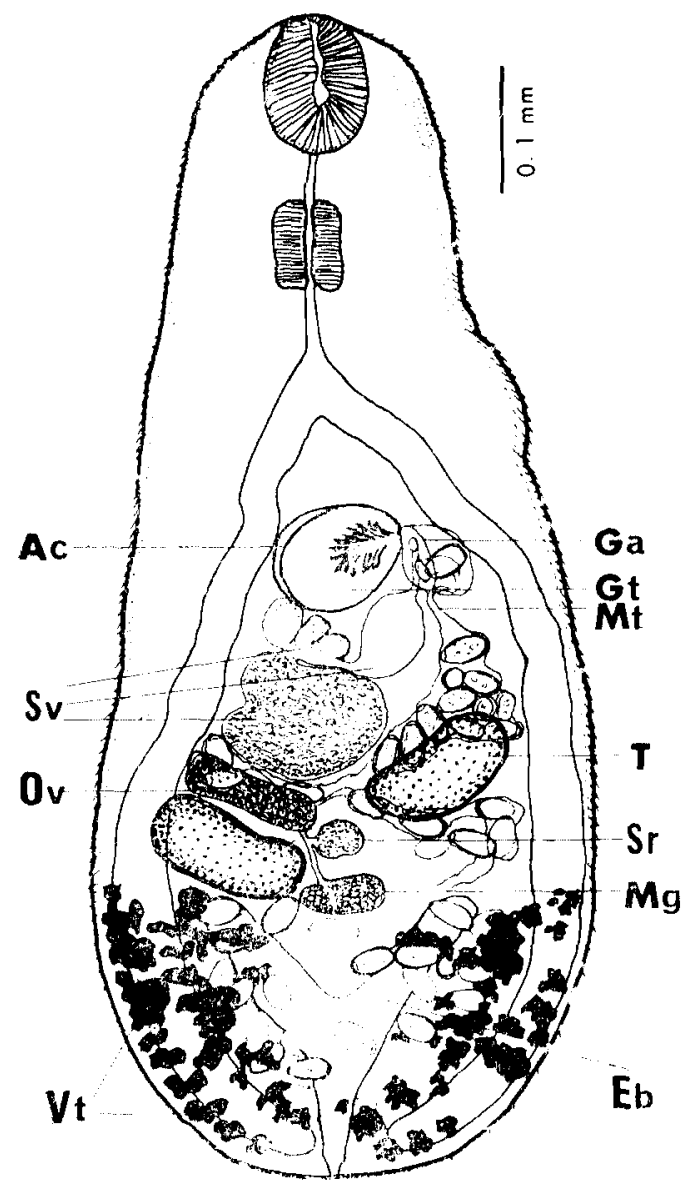

Fig. 5. Ventral view of Stictodora sp. showing illustrations of body organs.

¿Ac: acetabulum, Ga: genital atrium, Gt: gonotyl, Mt: metraterm, $\mathrm{S}_{\mathrm{v}}$ : seminal vesicle, Ov: ovary, T: testis, Sr: seminal receptacle, $\mathrm{Vt}$ : vitellaria, Eb: excretory bladder, $\mathrm{Mg}$ : Mehlis' gland] to posterior end of body. Ventral sucker slightly embedded in parenchyma, under gonotyl. Gonotyl ovoid, not enveloping genital sinus, $0.08 \mathrm{~mm}$ in diameter and armed with $12 \sim 15$ spines (Figs. 2 \& 4).

Testes obliquely tandem, $0.12 \sim 0.17 \mathrm{~mm}$ by $0.07 \sim 0.11 \mathrm{~mm}$ in size, and located in anterior part of posterior body. Seminal vesicle constricted into 3 or 4 saccules, thin-walled, and lying between acetabulum and ovary. Ejaculatory duct short, opened into genital atrium separately from metraterm. Metraterm short, ventral to ejaculatory duct. Ovary oval, $0.09 \sim 0.11 \mathrm{~mm}$ by $0.04 \sim 0.05 \mathrm{~mm}$ in size, immediately in front of right testis. Seminal receptacle spherical and median to right testis. Laurer's canal and egg shell gland present. Uterus long, distributed in posterior half of body, with many windings. Eggs oval (Fig. 3), dark brown, thick-shelled without muskmelon pattern, and $0.034 \sim 0.038$ $\mathrm{mm}$ by $0.020 \sim 0.023 \mathrm{~mm}$. Vitellaria distributed in peripheral area of post-testicular region. Excretory vesicle $\mathrm{Y}$-shaped.

\section{DISCUSSION}

Morphologically the genus Stictodora is closely related to the genus Galactosomum. Yamaguti (1939) differentiated Stictodora from Galactosomum with following characters; constricted and thin-walled seminal vesicle, post-testicular distribution of vitellaria, absence of muscular bulb in genital atrium, separate opening of ejaculatory duct and metraterm, and Y-shape excretory vesicle. Our specimens unquestionably belong to the genus Stictodora.

The genus Stictodora was originally established by Looss (1899) with the type species, $S$. sawakinensis. Since then more than 20 species have been reported in the world literature (Yamaguti, 1958; Velasquez, 1973; Kinsella and Heard, 1974), although several of them may be synonym of the other. In southeast Asia, 12 species have been described so far; 7 in Japan (Onji and Nishio, 1916; Yamaguti, 1939), 4 in the Philippines(Africa and Garcia, 
Table 1. Stictodora spp. reported from southeast Asia

\begin{tabular}{|c|c|c|}
\hline Species & Host & Reporter (Year) \\
\hline \multicolumn{3}{|l|}{ Japan } \\
\hline S. adulescentium & sea-gull & Onji and Nishio (1916)* \\
\hline S. pusillum & sea-gull & Onji and Nishio (1916)* \\
\hline S. perpendiculum & sea-gull, dog, cat & Onji and Nishio (1916)* \\
\hline S. fuscatum & cat & Onji and Nishio $(1916)^{*}$ \\
\hline S. mergi & sea-gull & Yamaguti $(1939)^{*}$ \\
\hline S. japonica & sea-gull & Yamaguti $(1939)^{*}$ \\
\hline S. lari & sea-gull & Yamaguti $(1939)^{*}$ \\
\hline \multicolumn{3}{|l|}{ Philippines } \\
\hline S. sawakinensis & dog, cat & Africa et al. (1940) \\
\hline \multirow[t]{2}{*}{ S. manilensis } & $\operatorname{dog}$ & Africa and Garcia (1935)* \\
\hline & sea-gull, dog, cat & Africa et al. (1940) \\
\hline S. guerreroi & sea-gull, dog & Garcia and Refuerzo (1936) \\
\hline S. tanayensis & kitten & Velasquez $(1973)^{*}$ \\
\hline \multicolumn{3}{|l|}{ China } \\
\hline$S$. hainanensis** & $\operatorname{dog}$ & Kobayasi $(1942)^{*}$ \\
\hline S. manilensis & dog, cat & Chen (1951) \\
\hline
\end{tabular}

* Reported as a new species

** Synonym of S. manilensis (Chen, 1951; Velasquez, 1973)

1935; Garcia and Refuerzo, 1936; Velasquez, 1973) and 1 in China (Kobayasi, 1942) (Table 1). No report is available on Stictodora species in Korea.

Differential points of each species are one or more of followings; body size, egg size, comparative size and position of organs, morphology of the ventrogenital sac, and so on. Among them, the ventrogenital sac, especially the number and arrangement of chitinous spines on its gonotyl, is regarded a most important key for the species differentiation (Chen, 1951; Bearup, 1961).

Both of the present two specimens reveal a common feature of genital sac, which appear as 2 partially overlapping rings, gonotyl and genital sinus (Figs. $2 \& 4$ ). The spines on gonotyl are one group near its apex, radially arranged, and $12 \sim 15$ in number. Stictodora manilensis Africa and Garcia, 1935 (syn. S. hainanensis Kobayasi, 1942; Table 1) can be a candidate for the present specimens, considered the morphology of genital sac and number of gonotyl spines. S. fuscatum (Onji and Nishio, 1916 \& 1924) also appears to be a possible species to identify our specimens with, although in this species exact number of gonotyl spines is not known.

S. fuscatum was originally described as Cornatrium fuscatum in Japan with 3 other new species (Onji and Nishio, 1961 \& 1924). Later Yamaguti(1939) transfered them into the genus Stictodora Looss, 1899. In the meantime $S$. manilensis was described as a new species in Manila, Philippines (Africa and Garcia, 1935). Morozov(1952) considered S. manilensis a synonym of $S$. sawakinensis. However, they appear to be distinct from each other in their gonotyl structure; armed with numerous, up to 78 , spines arranged in 6,10 rows in S. sawakinensis (Witenberg, 1929; Kobayasi, 1968) while armed with $12 \sim 15$ long triangular hook-like spines in S. manilensis (Africa and Garcia, 1935; Chen, 1951).

Reviewing the literatures on Stictodora spp., the present authors came to a strong impression that $S$. manilensis should have been the same species as $S$. fuscatum. They each other reveal very similar morphology, especially in the appearance of ventrogenital sac and other genital 
organs, in spite that the number of gonotyl spines is not known in S. fuscatum. It seems likely that Africa and Garcia(1935) were not aware of the pre-existence of $S$. fuscatum under a different genus when they described $S$. manilensis as a new species. Appreciable difference between the two species is only in the size of eggs; $25 \sim 26$ by $14 \sim 15 \mu \mathrm{m}$ for $S$. manilensis (Africa and Garcia, 1935) and $35 \sim 37$ by $22 \sim$ $24 \mu \mathrm{m}$ for $S$. fuscatum (Onji and Nishio, 1924). Larger eggs of $S$. manilensis, however, have also been reported; $25.0 \sim 32.5$ by $17.5 \sim 20.0$ $\mu \mathrm{m}$ in the Philippines (Velasquez, 1973) and 38 by $26 \mu \mathrm{m}$ in Hong Kong (Chen, 1951). These discrepancy may have been due to different status of specimens measured; fresh, fixed or stained.

In our specimens measured under fixation the egg size was $34 \sim 38$ by $20 \sim 23 \mu \mathrm{m}$, by which they are more compatible with $S$. fuscatum than any other species. Final identification is, however, deferred until more worms are obtained. Observation of further specimens would make the diagnosis clear and provide informations on the validity of Stictodora species.

It is noteworthy that Stictodora sp. can infect human host. Of 22 ever-reported species (Yamaguti, 1958; Velasquez, 1973; Kinsella and Heard, 1974), 11 were found only from birds, 5 were from birds and mammals, and 6 were from mammals excluding man. Hereafter Stictodora sp. ( $S$. fuscatum) is included in the list of flukes that can occur in human intestine. Brackish water fishes are known to harbour the metacercariae of Stictodora sp. (reviewed by Yamaguti, 1958), but no report is available on intermediate hosts in Korea. Clinical details of this patient were described in other papers (Seo et al., 1984 a \& b; Chai et al., 1984).

\section{REFERENCES}

Africa, C.M. and Garcia, E.Y. (1935) Heterophyid trematodes of man and dog in the Philippines with descriptions of three new species. Phil. J. Sci., $57: 253-267$.

Africa, C.M., de Leon, W. and Garcia, E.Y. (1940)
Visceral complications in intestinal heterophyidiasis of man. Acta Med. Philippina, Monogr. Ser. No. 1:1-132.

Bearup, A.J. (1961) Observation on the life cycle of Stictodora lari (Trematoda: Heterophyidae). Proc. Linnean Soc. New South Wales, 136(3):251257.

Beaver, P.C., Jung, R.C. and Cupp, E.W. (1984) Clinical Parasitology (9th ed.). pp.478-481. Lea \& Febiger, Philadelphia.

Chai, J.Y., Seo, B.S. and Lee, S.H. (1984) Studies on intestinal trematodes in Korea XI. Two cases of human infection by Heterophyes heterophyes nocens. Korean J. Parasit., 22(1):37-42.

Chen, H.T. (1951) Stictodora manilensis and Stellantchasmus falcatus from Hong Kong, with a note on the validity of other species of the two genera (Trematoda: Heterophyidae). Lingnan Sci. J., 23: 165-175.

Garcia, E.Y. and Refuerzo, P.G. (1936) Two more species of the genus Stictodora Looss, 1899, in the Philippines with description of a new species. Phil. J. Sci., 60 (2): 137-141.

Ito, J. (1964) Metagonimus and other human heterophyid trematodes. Progress of Med. Parasit. in Japan, 1:317-393.

Kinsella, J.M. and Heard, R.W.III. (1974) Morphology and life cycle of Stictodora cursitans n. comb. (Trematoda: Heterophyidae) from mammals in Florida salt marshes. Trans. Am. Microsc. Soc., 93(3) :408-412.

Kobayasi, H. (1942) Studies on trematoda in Hainan Island II. Trematoda found in the intestinal tracts of dogs by experimental feeding with certain fresh and brackish water fish. Jap. J. Med. Sci. Path., 6(3) :187-227.

Looss, A. (1899) Weitere Beiträge zur Kenntniss der Trematodenfauna Aegyptens. Zool. J., 12:521-784. Morozov, F.N. (1952) Heterophyoidea Faust, 1929. In Skrjabin, K.I.: Trematodes of animals and man, 6:153-615 (Russian Text).

Onji, Y, and Nishio, T. (1916) On the trematodes whose second intermediate hosts are fishes from brackish water. Chiba Igaku Semmon Gakko Zasshi, 81 \& 82:229-249 (in Japanese).

Onji, Y. and Nishio, T. (1924) A monograph of intestinal trematodes. Chiba Igakkai Zasshi, 2(3): 113-161.

Seo, B.S., Lee, S.H., Chai, J.Y. and Hong, S.J. (1984a) Studies on intestinal trematodes in Korea 
XII. Two cases of human infection by Stellantchasmus falcatus. Korean J. Parasit., 22(1):43-50.

Seo, B.S., Lee, S.H., Chai, J.Y. and Hong, S.J. (1984) Studies on intestinal trematodes in Korea XIII. Two cases of natural human infection by Heterophyopsis continua and the status of metacercarial infection in brackish water fishes. Korean J. Parasit., 22(1):51-60.

Velasquez, C.C. (1973) Observations on some Hetero- phyidae (Trematoda: Digenea) encysted in Philippine fishes. J. Parasit., 59(1):77-84.

Yamaguti, S. (1939) Studies on the helminth fauna of Japan Part 25. Trematodes of birds, IV. Jap. J. Zool., 8(2):131-210.

Yamaguti, S. (1958) Systema Helminthum. Vol. 1. The Digenetic Trematodes of Vertebrates. Part I. pp. 699-724 \& 865-885. Interscience Publishers, New York.

\title{
푸굼뭋초록 $=$
}

\section{Stictodora sp. (Trematoda; Heterophyidae)의 인체기생 1례}

\author{
서울대학교 의과대학 기생충학교실 및 풍토병연구소, 경상대학교 의 과대학 기생총학교실* 및 \\ 인하대학교 의과대학 기생충학교실** \\ 채종일 · 홍성종* - 이순형 - 서병선**
}

이형흡충류의 하나인 Stictodora속 홉충 2마리가 구충제 및 하제를 투여한 24세 남자환자의 설사변에서 검출되 었다. 충체는 길이 $0.90 \sim 0.98 \mathrm{~mm}$, 푹 $0.38 \mathrm{~mm}$ 로 소형이뎌 특이한 벅훕반-생식반 (ventrogenital) 장치가 있고 생식공과 별개인 gonotyl(12 15개의 미소한 간고리 보유)을 가지고 있었다. 충체는 형태학적으로 Stictodora fuscatum (Onji and Nishio, 1916)과 매우 비슷하였으나 다수의 총체률 획득할 때까지 확정적인 종 동정은 보류 하였다. 환자는 숭어, 농어 등 반염수산 어류를 즐겨 생식한다고 하였다. 이들이 Stictodora sp.는 물론 따로 보 고한 3종류 이형흡충의 감염원이었을 것으로 추측된다. 이 증례는 문현상 Stictodora속 홉충의 최초 인체기생례 에 해 담된다. 